Article

\title{
An Interdisciplinary Scientific and Mathematic Education, Addressing Relevant Social Problems Such as Sexist Hate Speech
}

\author{
M. Teresa Sánchez-Compaña *, Cristina Sánchez-Cruzado $\mathbb{D}$ and Carmen Rosa García-Ruiz \\ Department of Didactics of Mathematics, Social Sciences and Experimental Sciences, Faculty of Education \\ Sciences, Teatinos Campus, University of Málaga, 29071 Malaga, Spain; cristinasanchez@uma.es (C.S.-C.); \\ crgarcia@uma.es (C.R.G.-R.) \\ * Correspondence: teresasanchez@uma.es
}

Received: 29 September 2020; Accepted: 2 November 2020; Published: 25 November 2020

\begin{abstract}
The intention of this article is to share research taken from the initial training of secondary education pre-service teachers, in which college professors from mathematics and social sciences education participate. There are numerous studies regarding curriculum integration. However, there is insufficient research that offers insight into how different forms of disciplinary thought may come together in the design and development in practice for an educational purpose. The research professors carried out a qualitative investigation, working with two pre-service teacher groups from the fields of mathematics and social sciences. We used a validated research instrument to analyze how interdisciplinary educational proposals are developed, and how said proposals can be used to understand our social reality. Through an integrated project, pre-service teachers addressed sexist hate speech taken from different contexts. They designed didactic proposals, with mathematical contents, which allow high school students to argue with data and create counter-narratives, which softened or eliminated the sexist hate speech Among the conclusions, we may emphasize the value of pre-service teachers identifying their strengths in order to use the mathematical and social thought processes in an autonomous and creative way, thereby developing the instrumental, functional, and formative character in mathematics education.
\end{abstract}

Keywords: hate speech; integrated curriculum; mathematics education; pre-service teacher; sexism

\section{Introduction}

In general, education must allow for the student body to achieve a certain level of physical, personal, social, and moral autonomy [1]. One of its main tasks must be to create a socially responsible and sufficiently autonomous citizenry. Scientific education and, more specifically, mathematics education, must go beyond mere theoretical learning of decontextualized content. Mathematics and science curriculum should not only contain a cognitive aspect, but also highlight the formative value of mathematical teaching and its relation to the affective field [2]. It is necessary for any educational practice to contemplate the development of the mathematical competence of the student body. However, it is even more necessary to motivate students to develop their own autonomy and critical thinking skills, as well as their self-confidence in the learning process [3]. On the other hand, it is essential to always be aware that mathematical knowledge and education must be developed from real-life approaches, and correctly contextualize and solve real-life problems [4].

Mathematics is mainly an interdisciplinary subject. It is related to virtually all aspects of life, and goes far beyond the scientific-technological field, such as the social sciences, the arts, music, or politics. Moreover, it has a threefold nature: Instrumental, functional, and formative [3,5]. In other 
words, mathematics education cannot, and should not, consist of simply teaching formulas and procedures. It must go beyond this by making its functionality visible in most of the aspects of life. Moreover, it must foster its formative aspect and instill the fundamental characteristics of future societies: Responsibility, respect, and empathy, among others.

Although the formative character of mathematics is essential to fully educate a 21st century society, it is often neglected in the teaching-learning process. Legislative measures are now being seriously considered, however, in order to promote this formative role [6].

Once we are able to carry out activities which cultivate this threefold character of mathematics (instrumental, functional, and formative) [3,5], it will be more feasible to achieve the intellectual, moral, and social autonomies needed for a student body and a future society. We interpret these different autonomies according to [7] (p. 229), such as "The capacity to think for oneself and generate information in order to solve real life problems (intellectual autonomy); the ability to make decisions with a social conscience when faced with real life problems (moral autonomy); and the capacity to make decisions applying social abilities and skills (social autonomy)".

The main focus of the activity carried out in the "Teaching Innovation and Introduction to Educational Research" course in the Masters in Secondary Education was to encourage the modeling of interdisciplinary tasks among teachers in training at the University of Malaga. It illustrated the need for a mathematical education with a formative role. It is especially important to advance this type of activity and practice in secondary schools, where different subjects are mostly taught separately from one another.

The aim of the training was for the pre-service teacher to design integrated mathematics and social science projects in high schools based on the identification of sexist hate speech, which then allowed his or her students to construct counter-narratives based on mathematical content.

\subsection{The Interdisciplinary and Curricular Integration}

In pedagogical literature, we find many references in favor of [8], and against [9], the importance of the disciplines in the organization of the curriculum. The bibliographic reviews which have focused on analysis of disciplinary knowledge observe that the terms multidisciplinary, interdisciplinary, and transdisciplinary are used equally. Scenarios in which these three concepts could be strategically combined and used to bring forward the practice of integrating knowledge were examines by [10]. Authors like [11] focus on educational practice from a historical approach, and use the term interdisciplinary and curriculum integration, as in our case, to refer to the connection between different disciplines with an educational purpose.

From our perspective, the interdisciplinary nature must not lose its character as a social democratic process. Instead, it should create the fundamental value of educational integration. This can be found in the implied ideology in disciplinary knowledge. In the same way, the influences which shape students' representations must always consider the current social and scientific problems. In this way, we may identify with the original traditional mathematics teaching for the curricular integration, which emerged in the 1950s. This was organized around problems related to teaching content or real-life problems. The main idea revolves around the fact that learning in both science and math is a social process which is based on the social, human, and interpersonal nature of education. This is often ignored due to the centrality of teaching to acquire mathematical techniques and the desire to achieve an "efficient" scientific-mathematical education [12].

Some research carried out in the field of science uses art as an evaluation tool for scientific activities [13]. Other researchers have used the integration of biology and visual arts to assess the resistance that teachers experience in order to develop interdisciplinary educational proposals, and the capacity pre-service teachers have to make interdisciplinary connections [14].

It is quite interesting to observe the work of [15], which investigate the application of a professional development model focused on the arts and sciences. This model can be used effectively for teachers 
in designing interdisciplinary practices, though most of the research has been done exclusively in secondary education.

It is pertinent to highlight the contribution of [16], who, without losing sight of the educational purposes and the cultural value of science and mathematics, has developed a model of five thematic categories: (1) Content integration, (2) facilitating knowledge building, (3) prejudice reduction, (4) social justice, and (5) academic development [16]. This model encourages pre-service teachers to create authentic and successful learning experiences, which reinforce interdisciplinary learning and teaching.

In the 1990s, the research of $[17,18]$ emerged, pioneering the development of integrated learning. The emergence of these studies coincides with two elements: The educational reforms of the 1990s which supported an integrated curriculum in the USA and Canada (and later spread to Europe and the rest of the world); the STEM education movement, which is based on the idea of integrating the curriculum from concepts of science, technology, engineering, and mathematics [19]. Together these elements represent an important effort to broaden the theoretical framework, which interprets scientific learning in terms of conceptual and procedural understanding [20].

Works such as the progressive education theory by John Dewey address curricular integration regarding educational practice. Dewey organized the curriculum around social problems, in order to analyze and resolve them using disciplinary knowledge and methods. The idea is masterfully synthesized by [21]. The author defined the integrated curriculum as the application of the methodology and language of different disciplines, which can address a particular theme, question, problem, subject, or experience.

It is demonstrated how different beliefs and perceptions of curricular integration lead to different practices among teachers [22]. Therefore, the research carried out was deeply committed to knowing the various needs, challenges, and obstacles presented to each individual. Moreover, it looked for ways to overcome these obstacles. The results revealed that although many teachers had insecurities, they were interested in integrated approaches. Due to this, numerous researchers have made an appeal to introduce this type of education in teacher training [23].

One could argue that the educational reforms and learning standards of the 1990s had repercussions in the university and especially in interdisciplinary models of teacher training. In this sense, the initial research of [24] stands out, which was focused on teachers and students. The results coincided with other research in such a manner that integrated teaching was considered complex and difficult, albeit necessary [25]. In short, what it revealed was the need for a profound change in the university teaching culture and identity [26].

There is research in fields which rarely connect with one another such as philosophy and biology [27], or literature and mathematics [28]. However, the integration of forms of knowledge, such as science and mathematics, play an important role in research [29]. This has focused on shedding the light on the confusion generated by interdisciplinary approaches among teachers [30], on the mathematical reasoning formed through integration, as well as the need for literacy which improves reading and writing in mathematics [24].

Regarding the teaching of social sciences, with an eminently interdisciplinary curriculum, two models have been chosen for content integration. We find proposals around key concepts that structure the knowledge of various disciplines [31], following the North American tradition of social studies and, especially, the work of Hilda Taba or Richard Gross. On the other hand, there are researchers who support the integration of curriculum around problems, topics, or centers of interest which respond to social concerns. A formula inspired by [32] proposes methodological work projects which address problems and situations to solve in real life. These projects allow for learning in a procedural way, and interpret reality as active agents. This last formula has been the most accepted and is derived from a curriculum organized around relevant social problems [33] or socially relevant issues [34]; although both options integrate content for the understanding of social reality from a critical perspective.

Keeping the prior formula in mind, our study deals with how to bring together mathematical and social thought, or how to establish relationships between mathematical and social concepts which 
allow us to validate or reject reasoning from a critical perspective. Mathematical thinking should be understood as the ability to think in numerical terms to generate logical reasoning [3]. That is, to construct a concept and meaning of numbers to solve a problem. Social thought is difficult to define due to its nature and complexity of its conceptual diversity [35]. It is developed by enhancing skills, such as empathy, abstraction, inference, evaluation, and criticism, which can be used to judge social content and address moral dilemmas. According to [36], the variety of social disciplines, which could potentially contribute scientific knowledge to the school curriculum, can only be articulated by addressing the formation of social thought in the classroom. It becomes critical social thought when it contemplates the ideological nature of knowledge and questions its own beliefs. This is a fundamental part of social science teaching [37], but it is absent from the classroom due to resistance from teachers and the difficulty of its development [38].

\subsection{Hate Speech and Sexist Hate Speech}

In our research, we have promoted the integration of mathematical and social thought from projects that address sexist hate speech. Hate speech is used as a defense strategy with an ideological and political connotation that "constructs and locates the others out of the people by making them objects of discrimination and exclusion" ([39], p. 29). It is used to attack people and groups [40] based on their ethnic origin, religion or gender [41]. Liri Kopaçi-Di Michele notes that "sexist hate speech is a form of "social shaming" that aims to degrade women, instill fear and insecurity thus contributing towards maintaining and reinforcing a gender hierarchy and patriarchy in public places" [42]. It is complicated to make a full review of educational research in this field, but one can observe the most recent research done by [43] who, along with experts in citizenship education from four countries, investigate how digital hate speech is perceived.

Hate speech, specifically sexist hate speech, is excessively normalized on TV, in the news, media, social networks, and in the professional and public lives of so many people. To some extent, it has found its way in all aspects of life, and has become a deep social problem to which we must find a solution. Raising awareness among students allows him or her to identify and counteract it by using critical thinking skills. The dducation system must provide tools to develop these kind of [6].

The issue must be addressed at the very beginning of teacher training. In this regard, we may consider courses such as "Teaching Innovation and Introduction to Educational Research". This course may offer the appropriate framework to carry out innovative education promoting interdisciplinary training, which can be used to confront this social problem.

The training strategy starts by illustrating the need for teachers to integrate disciplinary ideas and concepts in order to build a collaborative knowledge base regarding curricular integration. They learn how to apply different methods and vocabulary from separate disciplines in order to confront social issues, such as sexist hate speech.

\section{Materials and Methods}

We carried out research of a qualitative nature, based on hermeneutic rationality, where a description is given of a training program from the group of research professors, and an analysis of the integrated design carried out by the participating pre-services teachers is made.

The thematic area is that of interdisciplinary scientific education in initial training for pre-service teachers of secondary education. We consider our study relevant to the extent that scientific knowledge in Spanish secondary education is organized around logocentric criteria and appears disconnected from social reality and its problems. The fragmentation of knowledge hinders collaboration between education professionals from different areas of knowledge. It prevents them from understanding reality from different points of view, as well as integrating different systems of thought for its analysis and understanding. 


\subsection{Objectives}

The study aims to investigate how a pre-service teacher creates learning situations, which allow scientific and humanistic content to be associated with the development of integrated curriculum. From this premise, we asked ourselves the following research questions:

1. Is it possible to develop interdisciplinary education for understanding social reality that promotes intellectual, moral and social autonomy development?

2. Will the pre-service teachers organize an interdisciplinary curriculum in practice which gives meaning to our social reality based on democratic values?

The general objective linked to the first question is to discover if the pre-service teachers-regardless of their field of knowledge-share the opinion that teaching can be an activity aimed at analyzing our social reality in an ethical and moral way. The specific objectives would be to show how their knowledge and ways of thinking are modified by integrating models of scientific and humanistic rationality and, in turn, revealing if the educational objectives they set are the product of a process of dialogue and discussion.

The general objective linked to the second research question is connected with our intention to assess whether or not future teachers understand that the curriculum can indeed have a democratic dimension. The specific objectives are to show if they understand the integrated curriculum and the practice from their own social and cultural dimensions.

\subsection{Participating Population}

The participating college professors have experience in training for the integration of disciplinary knowledge in the areas of social and mathematical sciences in the Master's degree in secondary education teachers [5].

Together with the three research professors, 80 pre-service teachers have participated from the university's Master's degree in elementary and secondary education, technical college, and foreign language teaching. Thirty-six participants are specializing in mathematics and 44 of them in social sciences.

\subsection{Training Program}

The training program is based on the idea that no curriculum development can occur without teacher development [44], which is organized around the design of an integrated project, based on mathematics and social sciences/philosophy curricula.

The research professors followed one of the ten models identified by [45]: The integrated model, in which interdisciplinary teams designed curricular proposals around different themes or concepts. Teams worked across disciplines to find equivalent concepts and ideas around which to plan units of study and implement them together. The strategy is common in high school education and university education, and often carried out with topics typically found in the humanities. Admittedly, we faced a more complex model of integration, in which interests of pre-service teachers shaped the learning experience. The research professors were facilitators and also supporters of the four phases of [46], which involves organizing the curriculum around problems and themes that have personal and social meaning for students

Pre-service teachers worked in project focuses on looking for a particular social problem, which involves the dissemination of current opinion in different media, including social networks and conventional media, in the form of sexist hate speech. The commemoration of the International Day for the Elimination of Violence against Women, was the chosen day to implement the designed projects.

The pre-service teachers were organized into twelve interdisciplinary groups. Each groups independently chose varied contexts, from which they identified certain sexist hate speeches. They designed integrated projects, with the aim of making an educational proposal which promotes the 
elaboration of counter-narratives. This allowed them to scientifically educate as an exercise towards achieving a critical and reflexive citizenship.

The process began with an integration session, in an attempt at professional socialization, which merged disciplinary work groups to make them interdisciplinary. For this, research professors followed the collaborative teamwork model which allowed the pre-service teachers to plan, teach and develop their ideas [27]. The procedure for integration was developed with the selection and organization of topics, brainstorming, guiding questions, and activities [21].

It was designed to be open rather than linear, which provided a framework for the groups to shape different ideas. It started with the presentation introduction in the form of a teaching problem [47]: How to merge mathematical and social thinking in order to interpret a relevant social issue, related to gender inequality. The task required a practical solution from a complex pedagogical approach such as that of curricular integration.

The pre-service teachers groups put disciplinary ideas and concepts into practice for five sessions, which acted as connection operators for the critical understanding of the issue at hand. The distinctive feature of the experience was that the integration did not occur by resorting to disciplinary methodological structures, nor among areas of similar epistemological conceptions, such as math and science. It was brought together by converging mathematical and social thinking skills, which were then used to address the spread of sexist hate speech in the media and online. Moreover, it recognized this as a relevant social problem [48].

The resulting projects identified discourses of this nature, and at the same time, pre-services teachers' proposals promoted counteract hate speech by using different mathematical contents contextualized in these situations. Finally, they applied the integrated project into real-life educational contexts.

\subsection{Evaluation Tool}

We wanted to know if the pre-service teachers have developed an interdisciplinary educational proposal for understanding social reality that promotes the development of the differently defined autonomies. To analyze the results, we used a tool designed in the project framework called "Criteria and tools of evaluation, for analyzing the teaching and learning process", where the analysis theory categories are defined [49].

According to the authors [49], the categories were designed to consider the aim of the teaching-learning process in secondary education. This process should encourage competence development, so that educational practices promote the decision-making ability to solve problems in everyday life.

The selection tool (see Table 1) provides a model of indicators, which determine whether or not the teaching-learning process encourages the acquisition of different autonomies. We were able to observe that the didactic proposal allowed for developing the formative character of the mathematical educational practice, and not just the instrumental and functional ones, as this is not normally applied.

By analyzing the tool, we can confirm that there remains a need to design activities which promote the development of the students' attributes such as personal strategies, planning, observing, ability to model, and analyze situations. The latter attributes are related to the scientific practices of modeling, investigation, and argumentation [50-52]. Furthermore, these didactic proposals should encourage the development of moral and social autonomy. Examples of these could be empathy for others, respect, awareness of gender equality, etc.

From the categories that appear in Table 1, we carried out a deductive categorization of the didactic proposal, which pre-service teachers promoted and proposed [49]. Small expert research groups in didactics of mathematics carried out this categorization while doing so in the first phase as well. As detailed below, these research groups, reaching $92 \%$ agreement, made a comparison of the assigned categories. 
Lastly, those specialized in didactics of social science made the same categorization process in their group, also reaching roughly $90 \%$ agreement. From this, the study is considered validated by experts in this field.

Table 1. Instrument selected for analysis.

\begin{tabular}{|c|c|c|c|}
\hline Categories & Sub-Categories & & Indicators \\
\hline \multirow[t]{2}{*}{$\begin{array}{l}\text { Intellectual } \\
\text { Autonomy }\end{array}$} & $\begin{array}{l}\text { Attributes for Recognizing Actions } \\
\text { Related to Scientific Practices of } \\
\text { Modeling and Investigation }\end{array}$ & $\begin{array}{l}\text { Related to } \\
\text { Modeling }\end{array}$ & $\begin{array}{l}\text { Capacity to Form Questions. (II1) } \\
\text { Logical Reasoning. (II2) } \\
\text { Strategy-Organization-Planning. (II3) } \\
\text { Interpreting. (II4) } \\
\text { Technology-Manipulation. (II5) } \\
\text { Observation. (II6) } \\
\text { Prediction. (II7) } \\
\text { Initiative-Exploration. (II8) } \\
\text { Modeling-Representing. (IM1) } \\
\text { Analysis-Synthesis. (IM2) }\end{array}$ \\
\hline & $\begin{array}{l}\text { Attributes Related to } \\
\text { Scientific-Mathematical Behaviors }\end{array}$ & & $\begin{array}{c}\text { Criticism (IAC1) } \\
\text { Constant: Perseverance-Persistence } \\
\text { (related to divergent thought) (IAC2) } \\
\text { Rigorous: Demanding-Thorough (related } \\
\text { to rigor and honesty) (IAC3) } \\
\text { Creativity (related to divergent thought) } \\
\text { (IAC4) } \\
\text { Curiosity: Thought Flexibility (related to } \\
\text { divergent thought) (IAC5) } \\
\text { Self-Esteem-Self-Confidence (IAC6) }\end{array}$ \\
\hline $\begin{array}{c}\text { Social } \\
\text { Autonomy }\end{array}$ & $\begin{array}{l}\text { Attributes Related to the Scientific } \\
\text { Reasoning Experiences } \\
\text { Other Social Attributes }\end{array}$ & $\begin{array}{l}\text { Related to } \\
\text { Reasoning }\end{array}$ & $\begin{array}{c}\text { Sensible. (SA1) } \\
\text { Analog-Cooperative (SA2) } \\
\text { Communication-descriptive. (SA3) } \\
\text { Generosity. (S1) } \\
\text { Collaboration. (S2) } \\
\text { Adaptable. (S3) }\end{array}$ \\
\hline $\begin{array}{c}\text { Moral } \\
\text { Autonomy }\end{array}$ & Moral Attributes & & $\begin{array}{c}\text { Ethics Criticism. (M1) } \\
\text { Comprehension. (M2) } \\
\text { Awareness of Gender Equality. (M3) } \\
\text { Sustainable/Commitment to the } \\
\text { Environment/Healthy. (M4) } \\
\text { Empathy. (M5) } \\
\text { Respect. (M6) } \\
\text { Value of the Importance of Cultural } \\
\text { Heritage. (M7) } \\
\text { Justice/Impartiality (M8) }\end{array}$ \\
\hline
\end{tabular}

Source: Adaptation of the Evaluation Tool of [49].

\section{Results}

Firstly, the research professors positively valued the work of the pre-service teachers groups, who were able to independently select the social contexts, in which hate speech of a sexist nature is habitually developed. The various selected contexts were Social Invisibility of Women, Women in Sports, the Role of Women in History, Microaggressions in Everyday Life, Stereotypes in Professions, Implicit and Explicit Hate Speech in Music and Dance, Toxic Relationships, Housework, and Advertising (Table 2). The description of the selected context and sexist hate speech chosen is shown below. Each group chose the theme independently, considering that the selected hate speech should be of sexist nature. The pre-service teachers designed a teaching proposal, to visualize hate speech, and help their pupils to develop a counter-narrative. 
Table 2. Group, context, and identified sexist hate speech.

\begin{tabular}{cc}
\hline Group & Context \\
\hline Social Invisibility of Women: Throughout history and \\
among various cultures, women have been-and still \\
are-made invisible and devalued in their important \\
achievements in numerous fields such as science, art, \\
and culture. In recent history, and indeed in some \\
cultures of today, women are exclusively confined to \\
domestic and care duties and are looked down upon \\
and criticized when they make any attempt to engage \\
in a different activity
\end{tabular} . $\begin{gathered}\text { Women in Sports: Women have been displaced in the } \\
\text { world of sports, and are only allowed to participate } \\
\text { in those which are considered less important and less } \\
\text { valuable. } \\
\text { Women Mathematicians Hidden from History: } \\
\text { Women mathematicians have been repeatedly } \\
\text { hidden and brushed aside. Their work is neither } \\
\text { taken into account nor do they receive any } \\
\text { recognition. Their intellectual property is even stolen } \\
\text { in some cases, and their work in general is belittled. }\end{gathered}$

Microaggressions in Everyday Life: Many women experience socially-normalized microaggressions in everyday life.

Women in Professional Sports: All female athletes are paid less than their male counterparts and are considered less important in general. In advertisements and commercials, they are used as sex objects. In the press, more attention is paid to their physical appearances and their private lives than their athletic achievements, and rude and humiliating comments are often made about them in interviews or articles

Stereotypes In Music: Songs are full of humiliating expressions towards women-treating them like objects and inciting violence.

Toxic Relationships: Emphasis is placed on those relationships in which a woman is spoken to in a derogatory way-humiliated and insulted by the man

The Role of Women in Music and Dance: Far too often, women in entertainment are portrayed as sex objects, and in secondary roles accompanied by male protagonists. In sexually explicit dances, the man is always in the dominating position. On the other hand, in music festivals of any genre their presence is seen as ridiculous

Gender Violence: Gender violence is a reality, which can be seen on the news on a daily basis. We are constantly given details of how men exercised psychological, verbal, or physical violence on women. Verbal violence is full of hate speech and is the precursor to femicide

Phrases such as, "You are not useful", "you don't know how to do anything".

Those who play any sports which are deemed as "masculine" are even insulted. "Run like a girl" is an insult, whereas "run like a boy" is a compliment.

For example, Hypatia, one of the first women mathematicians ever recorded in history, suffered a smear campaign which ultimately triggered her brutal murder.

For example, in family gatherings they are often told that they know nothing about politics, sports or any other related matters, "Shut up, you don't know anything about politics". They are often catcalled in the streets, and used as commodities or methods of attraction in order to fill pubs-where much of this disrespect takes place ("You're dressed like a prostitute").

We found an article titled: "The List of International Hotties at the Rio Olympics".

Some of these lyrics are extremely explicit and evidently sexist, like "Grab her, hit her, spank her, hit her, take her out to dance 'cause she's down for anything. Hit her, spank her, grab her 'cause she's down for anything. Grab her, hit her, spank her" (Trebol Clan, "Grab her").

Jealous men may often destroy a woman's self-esteem, among other numerous examples. ("You are too stupid to think", "you are too fat to wear those clothes").

We found an article titled "Maluma Appears with a Group of Hotties on Stage."

"If you talk to me like that again, I'll kill you", "You're insane, I'm going to take your children away" 
Table 2. Cont.

\begin{tabular}{|c|c|c|}
\hline Group & Context & Identified Sexist Hate Speech \\
\hline G10 & $\begin{array}{l}\text { Comments in Press Headlines and Social Networks: } \\
\text { Headlines can often be found in which women are } \\
\text { despised. }\end{array}$ & $\begin{array}{l}\text { For example, the following adage was used in an } \\
\text { attempt to humiliate the president of Spain, in an } \\
\text { interview: "Don't cry like a woman what you } \\
\text { weren't able to defend as a man". Other more explicit } \\
\text { written remarks can be seen such as "Mayor of } \\
\text { Barcelona Will Not Abort Her Child: Ada Colau } \\
\text { Announces She is Pregnant at } 42 \text { Years of Age", "The } \\
\text { Sexually Frustrated Slut of CUP Says Children } \\
\text { Should Be Raised in Tribes" or "Porn, Feminazis, } \\
\text { Lesbians, Chapel-Raiding...The New Left" }\end{array}$ \\
\hline G11 & $\begin{array}{l}\text { Career and Job Stereotypes in Advertising: News } \\
\text { articles have appeared in which certain jobs were } \\
\text { seen as inappropriate for women. }\end{array}$ & $\begin{array}{l}\text { Potential negative effects which are unfounded were } \\
\text { attributed such as "The Murder of Maria Lage in } \\
\text { Vigo, Outcome of the Feminization of the Military } \\
\text { and Police Services." In general it is often suggested } \\
\text { that women are unable to carry out certain } \\
\text { professional activities, or do them correctly. }\end{array}$ \\
\hline G12 & $\begin{array}{l}\text { Housework: Many women are left to do various } \\
\text { domestic duties and are not paid or adequately } \\
\text { valued within the family unit. Housework is still } \\
\text { carried out mostly by women, and is not accounted } \\
\text { for in the family finances. }\end{array}$ & $\begin{array}{l}\text { The work carried out by these women is almost } \\
\text { entirely undervalued. One man who works outside } \\
\text { of his home said to his wife who stays and works at } \\
\text { home, "You don't do anything, I am the one who } \\
\text { does the real work, who earns the money." }\end{array}$ \\
\hline
\end{tabular}

The mathematical content that was used to construct counter-narratives is highlighted in Table 3. It also briefly describes a summary of some of the activities carried out and the counter-narrative developed by the high school students. We stress that all projects have the potential to raise awareness around gender equality, which can occur while working on certain mathematical content [48]. As educators, we are fully aware of the difficulty that this proposed project entails to the pre-service teachers. Nevertheless, the participants successfully and independently developed innovative and interesting activities with mathematical content. Moreover, they demonstrated the formative and functional character of mathematics and were able to analyze its relevance and usefulness in today's world.

Table 3. Group, context, mathematical content, proposed activities, and counter-narrative.

\begin{tabular}{|c|c|c|}
\hline $\begin{array}{l}\text { Group/ } \\
\text { Context/Mathematical } \\
\text { Content Used }\end{array}$ & $\begin{array}{l}\text { Brief Description of the Proposed Activities by the } \\
\text { Pre-Service Teachers for the Development of a } \\
\text { Counter-Narrative }\end{array}$ & $\begin{array}{l}\text { Developed Counter-Narratives } \\
\text { by High School Students }\end{array}$ \\
\hline $\begin{array}{l}\text { G1/Social Invisibility of } \\
\text { Women/Graph Theory }\end{array}$ & $\begin{array}{c}\text { Multiple questions are raised to generate debate around } \\
\text { what is the invisibility of a collective group, specifically } \\
\text { that of women. The responses are gathered with Post-it } \\
\text { notes and a graph is made using the ONODO } \\
\text { application. }\end{array}$ & $\begin{array}{l}\text { History is full of important } \\
\text { women in science, art or culture. } \\
\text { Women are useful, and they play a } \\
\text { really important role in our history. } \\
\text { Knowing our history will allow us } \\
\text { to value these women and their } \\
\text { works. }\end{array}$ \\
\hline $\begin{array}{c}\text { G2/Women in } \\
\text { Sports/Percentages and } \\
\text { Bar Graphs }\end{array}$ & $\begin{array}{l}\text { The students analyzed different sport activities using } \\
\text { percentages and bar graphs. They addressed the } \\
\text { different kinds of sports in which they and their peers } \\
\text { participate, clearly indicating certain patterns among } \\
\text { girls and boys in this field. }\end{array}$ & $\begin{array}{l}\text { They discovered that some of their } \\
\text { classmates play soccer, handball } \\
\text { and practice athletics. Women can } \\
\text { play whatever they want. }\end{array}$ \\
\hline $\begin{array}{l}\text { G3/Women } \\
\text { Mathematicians/Hidden } \\
\text { from History/Irrational } \\
\text { Numbers }\end{array}$ & $\begin{array}{l}\text { The activity was carried out by the first high school } \\
\text { course students, who had yet to learn irrational numbers. } \\
\text { They were given an analogy between women hidden in } \\
\text { the history of mathematics and the existence of irrational } \\
\text { numbers. This awoke a sense of awe and curiosity from } \\
\text { the students (in both a mathematical and historical sense) } \\
\text { and encouraged them to continue research on the life } \\
\text { and work of these women. }\end{array}$ & $\begin{array}{l}\text { They mostly knew of only male } \\
\text { mathematicians before this } \\
\text { experience. They then discovered } \\
\text { many women mathematicians, } \\
\text { and were shown how important } \\
\text { women and their works were in } \\
\text { this particular field. }\end{array}$ \\
\hline
\end{tabular}


Table 3. Cont.

\begin{tabular}{|c|c|c|}
\hline $\begin{array}{l}\text { Group/ } \\
\text { Context/Mathematical } \\
\text { Content Used }\end{array}$ & $\begin{array}{c}\text { Brief Description of the Proposed Activities by the } \\
\text { Pre-Service Teachers for the Development of a } \\
\text { Counter-Narrative }\end{array}$ & $\begin{array}{l}\text { Developed Counter-Narratives } \\
\text { by High School Students }\end{array}$ \\
\hline $\begin{array}{l}\text { G4/Microaggressions in } \\
\text { Everyday } \\
\text { Life/Mathematical } \\
\text { Modeling }\end{array}$ & $\begin{array}{l}\text { The students were faced with a "modeling" problem } \\
\text { regarding the economic benefits—-which may be subtle } \\
\text { and difficult to notice at first-of a bar or club that uses } \\
\text { the strategy of free admission for women. }\end{array}$ & $\begin{array}{l}\text { They became aware that using } \\
\text { women as an advertisement turns } \\
\text { women into objects. "I don't want } \\
\text { to be an object, I don't go into a bar } \\
\text { under those conditions. Nobody } \\
\text { has to say anything about me as an } \\
\text { object." }\end{array}$ \\
\hline $\begin{array}{l}\text { G5/Women in } \\
\text { Professional } \\
\text { Sports/Statistics }\end{array}$ & $\begin{array}{l}\text { A statistical survey was carried out which revealed, } \\
\text { through numerical evidence, the hate speech that is } \\
\text { generated day after day in the media and social networks, } \\
\text { regarding the role of women in professional sports. }\end{array}$ & $\begin{array}{l}\text { The list of tennis players in history } \\
\text { with the most titles starts with } \\
\text { Margaret Cour, followed by } \\
\text { Serena Williams and Stefanie Graf. } \\
\text { No men. }\end{array}$ \\
\hline $\begin{array}{l}\text { G6/Stereotypes in } \\
\text { music/Normal } \\
\text { Distribution }\end{array}$ & $\begin{array}{l}\text { The students classified the lyrics of several songs as } \\
\text { "sexist content", "romantic myth" and "healthy". This } \\
\text { classification was then analyzed and observed according } \\
\text { to Gauss' normal distribution or bell distribution. This in } \\
\text { turn generated a debate which revealed that many of us } \\
\text { "normalize" negative gender stereotypes in our daily } \\
\text { lives and in our emotional-personal relationships. }\end{array}$ & $\begin{array}{l}\text { They clearly identified aggressive } \\
\text { letters. They looked for other } \\
\text { kinds of songs without this } \\
\text { content. }\end{array}$ \\
\hline $\begin{array}{l}\text { G7/Toxic } \\
\text { Relationships/Integer } \\
\text { Numbers }\end{array}$ & $\begin{array}{l}\text { The activity is carried out with students who are } \\
\text { working on integer numbers. Its aim is to draw an } \\
\text { analogy between the positive and negative numbers } \\
\text { with toxic or positive behavior in a relationship. }\end{array}$ & $\begin{array}{c}\text { Be aware of how many } \\
\text { relationships are toxic, and avoid } \\
\text { those types of relationships. "You } \\
\text { are not going to tell me how I have } \\
\text { to dress and how I have to } \\
\text { behave". }\end{array}$ \\
\hline $\begin{array}{l}\text { G8/The role of women } \\
\text { in Dance/Statistics }\end{array}$ & $\begin{array}{l}\text { The presence of women in major music and dance } \\
\text { festivals is statistically analyzed. It shows that the role of } \\
\text { women is almost nonexistent, and mostly presented in a } \\
\text { degrading way that generates further hate speech. }\end{array}$ & $\begin{array}{l}\text { Students changed the press } \\
\text { headlines, writing "A Spectacular } \\
\text { Choreography group accompanies } \\
\text { Maluma on Stage". Nobody } \\
\text { focuses attention in their bodies. }\end{array}$ \\
\hline $\begin{array}{c}\text { G9/Gender } \\
\text { Violence/Percentages }\end{array}$ & $\begin{array}{c}\text { Press clippings are analyzed which show the percentages } \\
\text { dealing with women who have been murdered by their } \\
\text { male partners. }\end{array}$ & $\begin{array}{l}\text { Percentages amazed the students. } \\
\text { They said, "You never have to } \\
\text { speak to a woman like this." }\end{array}$ \\
\hline $\begin{array}{l}\text { G10/Comments on } \\
\text { Press Headlines and } \\
\text { Social } \\
\text { Networks/Integer } \\
\text { Numbers }\end{array}$ & $\begin{array}{l}\text { The words that appear in press clippings or found online } \\
\text { in social networks are classified as positive or negative. } \\
\text { An analogy is then made using integer numbers. }\end{array}$ & $\begin{array}{l}\text { Students changed the press } \\
\text { headlines, for instance writing, } \\
\text { "Mayor of Barcelona Ada Colau, } \\
\text { Announces the Happy News That } \\
\text { She Will Give Birth to a Baby in a } \\
\text { Few Months". }\end{array}$ \\
\hline $\begin{array}{l}\text { G11/Career and Job } \\
\text { Stereotypes in } \\
\text { Advertising/Percentages. } \\
\begin{array}{l}\text { G12/Housework/Monetar } \\
\text { Value. }\end{array}\end{array}$ & $\begin{array}{l}\text { Advertising clippings are shown which detail various } \\
\text { job stereotypes as well as the percentage, which } \\
\text { corresponds to professions that are seen as either } \\
\text { masculine or feminine. } \\
\text { A graph with the monetary value of different household } \\
\text { tasks is shown. Students are asked to fill out another } \\
\text { graph by gathering specific information of the tasks that } \\
\text { are performed in their households. Lastly, a debate is } \\
\text { generated after sharing the results. }\end{array}$ & $\begin{array}{l}\text { Students showed real women in } \\
\text { professions usually associated } \\
\text { with men. "Women can work in } \\
\text { whatever they want". } \\
\text { Students discovered the monetary } \\
\text { value of work at home. They } \\
\text { finished saying "You can't put a } \\
\text { price on the work my mother does } \\
\text { at home". }\end{array}$ \\
\hline
\end{tabular}

The data shows that the pre-service teachers developed various methods, which included debates, research, the use of smartphone applications and social networks, the development of panels, and role-playing games, among other things. This may suggest that future teachers will already have developed some autonomy and creativity in these areas. It also should be noted that they were able to identify their strengths and how to utilize them in order to achieve a positive layout and implementation of the activity.

Once the process was finished, the pre-service teacher groups presented a report detailing the design and execution of the educational proposal, while critically reflecting on their work. 
The categorization was carried out based on this report and on the analysis conducted by the research-educators throughout the entire process. The previously mentioned evaluation instrument was successfully used to achieve the results for a qualitative analysis.

The results of the categorization appear in Table 4, which shows how the attributes develop into the 12 designed and conducted projects. The first row shows the different didactic proposal groups, named by their group number. The first column shows the attribute with the code shown previously in Table 1 . In the followings columns, a " 1 " is written if the project presents the attribute, and a " 0 " if the attribute was not. For instance, if we describe the categorization of G1 work, looking at its column, we could say that the pre-service teachers came up with 26 of 30 attributes in their project, which are all the attributes except "Sensible", "Environment/Healthy", "Value of the Importance of Cultural Heritage", and "Justice/Impartiality".

Table 4. Categorization results of the didactic proposals.

\begin{tabular}{|c|c|c|c|c|c|c|c|c|c|c|c|c|c|c|}
\hline Attrib. & G1 & G2 & G3 & G4 & G5 & G6 & G7 & G8 & G9 & G10 & G11 & G12 & T At & T Au \\
\hline II1 & 1 & 1 & 1 & 1 & 1 & 1 & 1 & 1 & 1 & 1 & 1 & 1 & 12 & \\
\hline II2 & 1 & 1 & 1 & 1 & 1 & 1 & 1 & 1 & 1 & 1 & 1 & 1 & 12 & \\
\hline II3 & 1 & 1 & 1 & 1 & 1 & 1 & 1 & 1 & 1 & 1 & 0 & 1 & 11 & \\
\hline II4 & 1 & 1 & 1 & 1 & 1 & 1 & 1 & 1 & 1 & 1 & 1 & 1 & 12 & \\
\hline II5 & 1 & 1 & 1 & 1 & 1 & 1 & 1 & 1 & 1 & 1 & 1 & 1 & 12 & \\
\hline II6 & 1 & 1 & 1 & 1 & 1 & 1 & 1 & 1 & 1 & 1 & 1 & 1 & 12 & \\
\hline II7 & 1 & 0 & 0 & 1 & 0 & 1 & 0 & 0 & 1 & 1 & 0 & 1 & 6 & \\
\hline II8 & 1 & 1 & 1 & 0 & 0 & 1 & 1 & 1 & 1 & 1 & 0 & 0 & 8 & 177 \\
\hline IM1 & 1 & 1 & 1 & 1 & 1 & 1 & 1 & 1 & 1 & 1 & 1 & 1 & 12 & \\
\hline IM2 & 1 & 1 & 1 & 1 & 1 & 1 & 1 & 1 & 1 & 1 & 1 & 1 & 12 & \\
\hline IAC1 & 1 & 1 & 1 & 1 & 1 & 1 & 1 & 1 & 1 & 1 & 1 & 1 & 12 & \\
\hline IAC2 & 1 & 1 & 1 & 0 & 0 & 1 & 1 & 1 & 1 & 1 & 1 & 1 & 10 & \\
\hline IAC3 & 1 & 1 & 1 & 1 & 1 & 1 & 1 & 0 & 1 & 1 & 1 & 1 & 11 & \\
\hline IAC4 & 1 & 1 & 1 & 1 & 0 & 1 & 1 & 1 & 1 & 1 & 1 & 1 & 11 & \\
\hline IAC5 & 1 & 1 & 1 & 1 & 1 & 1 & 1 & 1 & 1 & 1 & 1 & 1 & 12 & \\
\hline IAC6 & 1 & 1 & 1 & 1 & 1 & 1 & 1 & 1 & 1 & 1 & 1 & 1 & 12 & \\
\hline SA1 & 1 & 1 & 1 & 1 & 1 & 1 & 1 & 1 & 1 & 1 & 1 & 1 & 12 & \\
\hline SA2 & 1 & 1 & 1 & 0 & 0 & 1 & 1 & 0 & 1 & 1 & 1 & 0 & 8 & \\
\hline SA3 & 1 & 1 & 1 & 1 & 1 & 1 & 1 & 1 & 1 & 1 & 1 & 0 & 11 & 51 \\
\hline S1 & 0 & 0 & 0 & 0 & 0 & 0 & 0 & 0 & 0 & 0 & 0 & 0 & 0 & \\
\hline $\mathrm{S} 2$ & 1 & 1 & 1 & 0 & 0 & 1 & 1 & 0 & 1 & 1 & 1 & 0 & 8 & \\
\hline S3 & 1 & 1 & 1 & 1 & 1 & 1 & 1 & 1 & 1 & 1 & 1 & 1 & 12 & \\
\hline M1 & 1 & 1 & 1 & 1 & 1 & 1 & 1 & 1 & 1 & 1 & 1 & 1 & 12 & \\
\hline M2 & 1 & 1 & 1 & 1 & 1 & 1 & 1 & 1 & 1 & 1 & 1 & 1 & 12 & \\
\hline M3 & 1 & 1 & 1 & 1 & 1 & 1 & 1 & 1 & 1 & 1 & 1 & 1 & 12 & 67 \\
\hline M4 & 0 & 0 & 0 & 0 & 0 & 0 & 0 & 0 & 0 & 0 & 0 & 0 & 0 & \\
\hline M5 & 1 & 1 & 1 & 1 & 1 & 1 & 1 & 1 & 1 & 1 & 1 & 1 & 12 & \\
\hline M6 & 1 & 1 & 1 & 1 & 1 & 1 & 1 & 1 & 1 & 1 & 1 & 1 & 12 & \\
\hline M7 & 0 & 0 & 0 & 0 & 0 & 0 & 0 & 0 & 0 & 0 & 0 & 0 & 0 & \\
\hline M8 & 0 & 0 & 1 & 1 & 1 & 0 & 1 & 1 & 1 & 1 & 0 & 0 & 7 & \\
\hline TOTAL & 26 & 25 & 26 & 23 & 21 & 26 & 26 & 23 & 27 & 27 & 23 & 22 & & 295 \\
\hline
\end{tabular}

On the right of the table, there are another two columns. The "T At" column shows the total number of times this attribute appears among all the experiences developed. The maximum value could be 12 for each attribute-each row-would mean that all groups worked on this attribute. The column " $\mathrm{T} \mathrm{Au}$ " shows the total result for each autonomy. The intellectual autonomy has 26 attributes associated, the social autonomy has six, and the moral one has eight attributes. Furthermore, at the bottom of the table one can see the total sums for each project of the developed and the total sum for all the projects. 
Note that despite the difficulty and lack of familiarity with the proposal, the pre-service teachers were able to structure activities which would indeed foster the main desired attributes of their future high school students.

In this study, 27 of the 30 attributes defined by [49] can be seen. The three attributes that did not appear are no less important such as "Generosity", "Sustainable/Commitment" to the Environment/Health" and "Value of the Importance of Cultural Heritage". In this case, the characteristic of the activity itself, focused on other attributes.

For these 12 groups, the total sum of attributes were 295. The mean is 24.6 attributes per group, that is, between 24 and 25 attributes. There was a minimum of 21 and a maximum of 27 of attributes developed.

Notice that in all of the projects brought up by the pre-service teachers, at least 21 of the 30 attributes appear in every didactic proposals. We may consider this to imply that the goal was met at a highly satisfactory degree. Those involved were able to design interdisciplinary didactic proposals which encouraged intellectual, social, and moral autonomy. To this, we must add that more than 25 of the desired attributes in the didactic proposals appear among seven of the 12 projects. This exceeds even the expectations of the professors, regarding the set objectives.

Of these attributes, 17 appear in all of the proposals: "Capacity to Form Questions", "Logic-Reasoning", "Interpreting", “Technology-Manipulation", “Observation", "Modeling-Representing", "Analysis-Synthetic", "Criticism", "Curiosity-Thought Flexibility (related to divergent thought)", "Self-Esteem and Self-Confidence", "Sensible", "Adaptable", "Ethics Criticism", "Comprehension", "Awareness of Gender Equality", "Empathy", and "Respect".

The attributes named "Strategy-Organization-Planning", "Rigorous-Demanding-Thorough (related to rigor and honesty)", "Creativity (related to divergent thought, and "Communication-Descriptive"), appear in 11 of the 12 proposals.

In two of the projects, 27 of 30 attributes emerged. One of them, the G9 group, dealt with gender-based violence and analyzed press clippings, using percentages of women who have been murdered by their partners. The other group, G10, used and analyzed social networks and press headlines, to make analogies with integers, classifying the comments as positive or negative.

We may observe that from the 295 attributes that appeared in the proposals designed by pre-service teachers, 177 attributes $(60 \%)$ corresponds to intellectual autonomy, 51 attributes $(17.29 \%)$ to social and 67 attributes (22.71\%) to moral autonomy. Usually, in a traditional proposal, $100 \%$ of the attributes promoted in educational practices focus solely on the development of intellectual autonomy. With this kind of experiment, we may note that important progress is being made in regards to a notable increase in the appearance of attributes corresponding to social and moral autonomy taken from integrated projects.

Another notable find from the study is how the pre-service teachers themselves have developed an exceptional capacity to carry out actions which have facilitated curricular integration. It is clearly evident that the pre-service teachers have been able to understand and interpret the situation presented to them. Even more so, they have questioned their own beliefs and those of other people involved in the activity. They have also recognized the implicit ideologies in the used disciplinary content and have built a social and scientific representation of reality. This created a situation of social and democratic development, which was achieved by the elaboration of integrated conceptual structures.

\section{Discussion and Conclusions}

Regarding the first research question, we asked ourselves if the pre-services successfully developed their intellectual, moral, and social autonomy based on the design of integrated projects. Specifically, we wanted to know if they understood teaching as an ethical and moral activity which commits itself to analysis of our social reality. In this sense we show with our analysis that they successfully designed and carried out integrated projects regarding sexist hate speech. They modified their knowledge and ways of thinking to integrate models of scientific and humanistic rationality. Our observation 
throughout the process of the integrated projects has indicated to us that this achieved thanks to the process of dialogue and democratic discussion among the work groups, which was done in order to find a common ground between both rationalities. In this way, they discovered the democratic value and meaning in mathematical learning.

We are aware that there remains a tendency to avoid controversial social and political issues in the classroom [53]. Resistances are overcome when we address these issues from the contributions of disciplinary knowledge when working with a curriculum organized around social issues which supports exploring more practical sources of knowledge.

In general, the results show the pre-service teachers promptly and fluency merged different conceptual structures. On the other hand, we must value the clarity with which it was demonstrated in the experiment that a cumulative or stereotyped conception of content is not necessary for the integration of disciplinary knowledge [54].

This leads us to highlight the benefits and needs of this type of practice, since we have shown that it is possible to acquire training which allows one to achieve a more than adequate development of intellectual, moral, and social autonomy. All of this is summed up in terms of the acquisition of attributes which make it possible to understand the present, and conceive the future [49], with the aim of adapting to the environment, organizing it, and transforming it. This creates alternatives which allow for a scientific literacy of citizens while at the same time improving the individual and collective situation from moral/social actions. This in turn will lead to complete social and human development [7].

Regarding the second question, we wanted to know if the pre-service teachers designed an interdisciplinary curriculum which gave meaning to the social reality from democratic values. In this sense, we wanted to know if, by introducing social and cultural content, linked to environmental problems, he or she understood that the curriculum can indeed possess a democratic dimension.

In general terms, our results brought us closer to the traditional interpretation regarding the integrated curriculum which sees education as a democratic process [55]. More recently, ideas are changing from social vocation to being presented with theories of learning and neuroscience, which are more concerned with understanding how the brain works and more focused on student-centered learning [56]. Our research shows that the implementation of processes that encourage the development of critical thinking, creative thinking and skills such as observation, deduction, classification, analysis, decision-making, and communication. By implementing these elements and joining different subjects, the thought process is shown as a complex, relational and interconnected experience [57], insofar as it addresses environmental problems, such as sexist hate speech.

Pre-service teachers-in-training acted as critical curricular agents [58] whose ideas and experience with other pre-service teachers from different areas of knowledge in the planning and development of educational practice, developed a more holistic understanding of reality.

We agree with [59] in pointing out that research regarding curriculum integration should be directed, among other aspects, to examine what pedagogical knowledge is necessary to develop the ability to integrate the curriculum. It also should indicate around what themes, and with what practical experiences, this should occur. We believe that our work offers key elements to start on that path. More research is needed to know how other pre-service teachers may develop the ability to promote educational experiences, which integrate knowledge into practice.

The main limitation or weakness of this research may be found in its need for introducing other variables. We could have expanded the lines of our research, or analyzed different topics and used different analysis variables. One of those variables could have been to observe the interaction between the participating pre-service teacher groups and the evolution of their thoughts. In the same way, we could have analyzed the same variables for high school student groups. We will keep this idea in mind for future lines of research.

We also understand that this type of practice can help pre-service teachers to become aware of the need to adopt a social approach in the classroom, always from an interdisciplinary perspective. In this 
way, pre-service teachers could develop the instrumental, functional and, about all, formative character that a quality mathematics education entails [6]. We want to insist on the potential of humanities, science, and mathematics teaching to achieve scientific and technological literacy of the citizenry from a social and human approach.

Ultimately, it proved to be a relevant experience not only for curricular integration, but also insofar as a mathematical enculturation experience. Math was used as a vehicle for understanding sexist hate speech and to obtain personal meanings that encourage the critical awareness of pre-service teachers regarding these issues [12]. Mathematical reasoning has been successfully determined as a fundamental cultural value as it provides a more complete understanding of relevant social problems.

Author Contributions: Introduction, by M.T.S.-C., C.S.-C. and C.R.G.-R.; Materials and Methods, M.T.S.-C., C.S.-C. and C.R.G.-R. but Objetives, written by C.R.G.-R.; Participating Population, by M.T.S.-C., C.S.-C.; Training Program by C.R.G.-R.; Evaluation tool by M.T.S.-C., C.S.-C.; Results by M.T.S.-C., C.S.-C. and C.R.G.-R., where contents associated to Table 2 by C.R.G.-R., contents associated to Tables 3 and 4, by M.T.S.-C., C.S.-C. Discussion and Conclusions by C.R.G.-R. In general, data curation, M.T.S.-C., C.S.-C.; writing-original draft preparation, M.T.S.-C., C.S.-C. and C.R.G.-R.; writing-review and editing, M.T.S.-C., C.S.-C. and C.R.G.-R.; visualization, M.T.S.-C., C.S.-C. and C.R.G.-R.; supervision, M.T.S.-C.; project administration, M.T.S.-C. All authors have read and agreed to the published version of the manuscript.

Funding: This study is part of the following research projects: the field of mathematics and science teaching, PGC2018-094114-A-I00, "Didactic Analysis of Teaching and Learning Units in Math and Science Textbooks From a Gender Perspective", financed by the MINECO/MICIU, and by the innovation project "Developing Professional Teaching Skills Through the Study of Women Scientists and the Inverted Classroom." (PIE19-029) financed by the University of Malaga, in the citation of 2019-2021 and from the "Interdisciplinary Network with a Feminist Approach to Teacher Training". The field of Social Sciences teaching, and I+D Project "Teach and learn to interpret contemporary problems and conflicts. What do the Social Sciences contribute to the formation of a global citizenship?" Financed by the Ministry of Economy and Competitiveness (EDU2016-80145-P). Innovation project "Service-Learning as a methodological strategy for the training of transformative professionals" (PIE 17-135), financed by the University of Malaga in the 2017-2019 announcement.

Conflicts of Interest: The authors declare no conflict of interest. The funders had no role in the design of the study; in the collection, analyses, or interpretation of data; in the writing of the manuscript, or in the decision to publish the results.

\section{References}

1. López-Melero, M.; Mancila, I.; Sole, C. Escuela Pública y Proyecto Roma. Dadme una escuela y cambiaré el mundo. Rev. Interuniv. de Form. del Profr. 2016, 85, 49-56.

2. Rico, L. Diseño curricular en Educación Matemática: Una perspectiva actual. In Teoría y práctica en Educación Matemática Didáctica; Linares, E.S., Sánchez, V., Eds.; Alfar: Sevilla, Spain, 1990.

3. González Mari, J.L. Claves para una educación matemática humanista. UNO 2020, 88, 49-59.

4. Rico, L.; Flores, P.; Ruiz-Hidalgo, J.F. Enseñanza de las matemáticas con sentido. UNO Rev. de Didáctica de las Matemáticas 2015, 70, 48-54.

5. Sánchez-Compaña, M.T.; García-Ruíz, C.R.; Sánchez-Cruzado, C. La integración de pensamiento matemático y social. Una práctica en formación inicial del profesorado de educación secundaria. Investigaciones en Pensamiento Numérico y Algebraico; Codina, A., Moreno, M.F., Eds.; Universidad de Almería: Almería, Spain, 2019; pp. 179-195.

6. Duarte, I.; Sánchez-Compaña, M.T.; Arnal, M.; Sánchez-Cruzado, C. A Curricular Approach to Developing Autonomies Regarding Mathematics and Scientific education. In Conference Proceedings. New Perspectives in Science Education, 7th ed.; Pixel, E., Ed.; Libreriauniversitaria.it Edizioni: Florence, Italy, 2018; pp. 236-239.

7. Macías-García, J.A.; Martín-Gámez, C.; González, J.L.; García, F. Teleological structure of scientific and mathematical education. In Conference Proceedings. New Perspectives in Science Education, 7th ed.; Pixel, E., Ed.; Libreriauniversitaria.it Edizioni: Florence, Italy, 2018; pp. 227-230.

8. Applebee, A.N.; Adler, M.F. Interdisciplinary curricula in Middle and High School Classrooms: Case Studies of Approaches to curriculum and instruction. Am. Educ. Res. J. 2007, 44, 1002-1039. [CrossRef]

9. Sefton-Green, J.; Thomson, P.; Jones, K.; Bresler, L. (Eds.) Curriculum Integration and the Disciplines of Knowledge; Routledge: New York, NY, USA, 2011. 
10. Helmane, I.; Briška, I. What is Developing Integrated or Interdisciplinary or Multidisciplinary or Transdisciplinary Education in School? Signum Temporis 2017, 9, 7-15. [CrossRef]

11. Drake, S.M. Creating Standards-Based Integrated Curriculum: The Common Core State Standards Edition; A SAGE Company: Corwin, CA, USA, 2012.

12. Bishop, A.J. Enculturación Matemática. La Educación Matemática Desde una Perspectiva Cultural; Paidós: Barcelona, Spain, 1999.

13. Öztürk Yılmaztekin, E.; Erden, F.T. Investigating early childhood teachers' views on science teaching practices: The integration of science with visual art in early childhood settings. Early Child Dev. Care 2017, 187, 1194-1207. [CrossRef]

14. Schramm, S. Intellectual Tension: Connecting Biology and Visual Art in the Secondary Curriculum. Am. Second. Educ. 1999, 27, 3-16.

15. Richard, B.; Treichel, C.J. Increasing Secondary Teachers' Capacity to Integrate the Arts. Clear. House J. Educ. Strateg. Issues Ideas 2013, 86, 224-228. [CrossRef]

16. Hernandez, C.M.; Morales, A.R.; Shroyer, M.G. The development of a model of culturally responsive science and mathematics teaching. Cult. Stud. Sci. Educ. 2013, 8, 803-820. [CrossRef]

17. Morrow, L.M.; Pressley, M.; Smith, J.K. The Effect of A Literature-Based Program Integrated Into Literacy and Science Instruction on Achievement, Use, and Attitudes Toward Literacy and Science; Reading Research Report 37; National Reading Research Center: Athens, Greece, 1995.

18. Czerniak, C.M.; Weber, W.B.; Sandmann, A.; Ahern, J. A literature review of science and mathematics integration. Sch. Sci. Math. 1999, 99, 421-430. [CrossRef]

19. Satchwell, R.; Loepp, F.L. Designing and Implementing an Integrated Mathematics, Science, and Technology Curriculum for the Middle School. J. Ind. Teach. Educ. 2002, 39, 3. Available online: https://scholar.lib.vt.edu/ ejournals/JITE/v39n3/satchwell.html (accessed on 4 May 2020).

20. Rennie, L.J.; Venville, G.; Wallace, J. Learning science in an integrated classroom: Finding balance through theoretical triangulation. J. Curric. Stud. 2011, 43, 139-162. [CrossRef]

21. Jacobs, H. The teacher as designer: Integrating the curriculum. Int. Sch. J. 1998, 18, 22-33.

22. Wang, H.; Moore, T.J.; Roehrig, G.H.; Park, M.S. STEM Integration: Teacher Perceptions and Practice. J. Pre-College Eng. Educ. Res. 2011, 1, 1-13. [CrossRef]

23. Shernoff, D.J.; Sinha, S.; Bressler, D.M.; Ginsburg, L. Assessing teacher education and professional development needs for the implementation of integrated approaches to STEM education. Int. J. STEM Educ. 2017, 4, 13. [CrossRef]

24. Douville, P.; Pugalee, D.K.; Wallace, J.D. Examining instructional practices of elementary science teachers for mathematics and literacy integration. Sch. Sci. Math. 2003, 103, 388-402. [CrossRef]

25. Heimer, L.; Winokur, J. Preparing Teachers of Young Children: How an Interdisciplinary Curriculum Approach is Understood, Supported, and Enacted among Students and Faculty. J. Early Child. Teach. Educ. 2015, 36, 289-308. [CrossRef]

26. Sáez, I.A.; Berasategi Sancho, N. The integrated curriculum, university teacher identity and teaching culture: The effects of an interdisciplinary activity. J. New Approaches Educ. Res. 2017, 6, 129-135. [CrossRef]

27. Rhem, J.; Plank, K.M. Team Teaching: Across the Disciplines, Across the Academy; Stylus Publishing LLC: Sterling, VA, USA, 2018.

28. Ruiz, E.C.; Thornton, J.S.; Cuero, K.K. Integrating Literature in Mathematics: A Teaching Technique for Mathematics Teachers. Sch. Sci. Math. 2010, 110, 235-237. [CrossRef]

29. Berlin, D.F.; Lee, H. Integrating Science and Mathematics Education: Historical Analysis. Sch. Sci. Math. 2005, 105, 15-24. [CrossRef]

30. Bosse, M.J.; Faulconer, J. Learning and assessing mathematics through reading and writing. Sch. Sci. Math. 2008, 108, 8-19. [CrossRef]

31. Benejam, P. Didáctica y construcción del conocimiento social en la escuela. Pensam. Educ. 2002, 30, 61-74.

32. Kilpatrick, W.H. The Project Method. Teach. Coll. Rec. 1918, 19, 319-335.

33. García Pérez, F.F. Geografía, problemas sociales y conocimiento escolar. Anekumene 2011, 1, 6-21. [CrossRef]

34. Pagès, J.; Santisteban, A. Les Qüestions Socialment vives i l'Ensenyament de les Ciències Socials; Universidad Autónoma de Barcelona: Barcelona, Spain, 2011.

35. Newmann. Researching and Teaching Social Issues: The Personal Stories and Pedagogical Efforts of Professors of Education; Lexington Books: New York, NY, USA, 2006. 
36. Pagès, J. La formación del pensamiento social. In Enseñar y Aprender Ciencias Sociales, Geografía e Historia en la Educación Secundaria; Benejam, P., Pagès, J., Eds.; ICE-Horsori: Barcelona, Spain, 1998; pp. 152-164.

37. Wright, I. Making critical-thinking possible: Options for teachers. Soc. Educ. 1995, 59, 139-143.

38. Onosko, J.J. Barriers to promoting higher-order thinking in social studies. Theory Res. Soc. Educ. 1991, 19, 341-366. [CrossRef]

39. Ranieri, M. (Ed.) Populims, Media and Education. Challenging discrimination in Contemporary Digital Societies; Routledge: New York, NY, USA, 2016.

40. Council of Europe. We Can! Taking Action against Hate Speech through Counter Alter-Native Narratives. No Hate Speech Movement; European Youth Centre: Strasbourg, France, 2017.

41. Djuric, N.; Zhou, J.; Morris, R.; Grbovic, M.; Radosavljevic, V.; Bhamidipati, N. Hate Speech Detection with Comment Embeddings. In Proceedings of the WWW 15 Companion: Proceedings of the 24th International Conference on World Wide Web, Florence, Italy, 18-22 May 2015. [CrossRef]

42. Council of Europe. Seminar Combating Sexist Hate Speech. Report 10-12 February 2016; European Youth Centre: Strasbourg, France, 2016.

43. Estellés, M.; Castellvi, J. The Educational Implications of Populism, Emotions and Digital Hate Speech: A Dialogue with Scholars from Canada, Chile, Spain, the UK, and the US. Sustainability 2020, 12, 6034. [CrossRef]

44. Savage, J. Cross-Curricular Teaching and Learning in Secondary School; Routledge: New York, NY, USA, 2010.

45. Fogarty, R.; Pete, B.M. How to Integrate the Curricula; A SAGE Company: Corwin, CA, USA, 2009.

46. Beane, J.A. On the Shoulder of Giants: The Case for Curriculum Integration. Middle Sch. J. 1996, 28, 6-11. [CrossRef]

47. Lacueva, A. Integrar para educar mejor: Posibilidades y exigencias. Investig. en la Escuela 2008, 66, 43-53.

48. García Ruiz, C.R.; Zorrilla Luque, J.L. Educar para la ciudadanía frente a discursos de odio desde la prensa digital. Una experiencia en formación inicial del profesorado de Educación Secundaria. In Enseñar y Aprender Didáctica de las Ciencias Sociales: La Formación del Profesorado Desde una Perspectiva Socio-Crítica; Hortas, M.J., Dias, A., Eds.; Escola Superior de Educaçao de Lisboa y AUPDCS: Lisboa, Portugal, 2019; pp. 640-647.

49. Martín-Gámez, C.; Sánchez-Compaña, M.T. ¿Qué Atributos Deben Fomentarse Desde Educación Científico-Matemática Para la Ciudadanía del Siglo XXI? Available online: https://hdl.handle.net/10630/16137 (accessed on 4 May 2020).

50. Erduran, S.; Jiménez-Aleixandre, M.P. Argumentation in Science Education. Perspectives from Classroom-Based Research; Springer: Berlin, Germany, 2007.

51. Gilbert, J.; Justi, R. Modelling-Based Teaching in Science Education; Springer: Cham, Switzerland, 2016.

52. National Research Council [NRC]. A framework for K12 Science Education: Practices, Crosscutting Concepts and Core Ideas; National Academy Press: Washington, DC, USA, 2012.

53. Hargreaves, A.; Moore, S. Curriculum integration and classroom relevance: A study of teachers' practice. J. Curric. Superv. 2000, 15, 89-112.

54. Torres Santomé, J. Las culturas negadas y silenciadas en el currículum. Cuad. de Pedagog. 1993, 217, 60-66.

55. Beane, J. Curriculum Integration. Designing the Core of Democratic Education; Teachers College Press: New York, NY, USA, 1997.

56. Roegiers, X. Una Pedagogía de la Integración: Competencias e Integración de los Conocimientos en la Enseñanza; Fondo de Cultura Económica: Mexico, Mexico, 2010.

57. Badilla Saxe, E. Diseño curricular: De la integración a la complejidad. Actual. Investig. en Educ. 2009, 9, 1-13. [CrossRef]

58. Giroux, H. Los Profesores como Intelectuales: Hacia una Pedagogía Crítica del Aprendizaje; Paidós: Barcelona, Spain, 1990.

59. Heywood, D.; Parker, J.; Jolley, N. Pre-Service Teachers' Shifting Perceptions of Cross-Curricular Practice: The Impact of School Experience in Mediating Professional Insight. Int. J. Educ. Res. 2012, 55, 89-99. [CrossRef]

Publisher's Note: MDPI stays neutral with regard to jurisdictional claims in published maps and institutional affiliations. 